\title{
Marka Güven Ölçeğinin Türk Kültürüne Uyarlanması: Geçerlik ve Güvenirlik Çalışması

\author{
(Adapting Brand Trust Scale to Turkish Culture: Validity and Reliability Study)
}

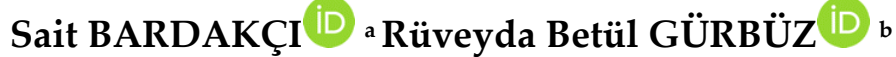

a Sivas Cumhuriyet Üniversitesi, İktisadi ve İdari Bilimler Fakültesi, İşletme Bölümü, Sayısal Yöntemler A.B.D., Sivas, Türkiye. sait bardakci@hotmail.com

b Sivas Cumhuriyet Üniversitesi, Sosyal Bilimler Enstitüsü, İşletme A.B.D., Sivas, Türkiye. ruveydabetulgurbuz@gmail.com

\begin{tabular}{|c|c|}
\hline MAKALE BİLGİSİ & ÖZET \\
\hline Anahtar Kelimeler: & $\begin{array}{l}\text { Amaç - Bu araştırmanın amacı, Delgado-Ballester (2004) tarafından geliştirilen Marka Güven Ölçeği } \\
\text { 'nin Türk kültürüne uyarlanması ve geçerlik ve güvenirlik analizlerinin yapılmasıdır. }\end{array}$ \\
\hline $\begin{array}{l}\text { Marka Güveni Ölçeği } \\
\text { Güvenirlik, Geçerlik }\end{array}$ & $\begin{array}{l}\text { Yöntem - İlk aşama olarak orijinal ölçek araştırmacılar tarafından Türkçeye çevrilmiş ve altı } \\
\text { uzmanın görüşüne başvurularak ölçeğin Türkçe formu düzenlenmiştir. Ölçeğin dil eşdeğerliğine } \\
\text { sahip olup olmadığı korelasyon analiziyle test edilmiştir. Ölçeğin yapı geçerliği açımlayıcı faktör } \\
\text { analizi ve doğrulayıcı faktör analizi kullanılarak, güvenirliği ise Cronbach } \alpha \text { katsayısı hesaplanarak } \\
\text { ve test-tekrar-test yöntemi kullanılarak incelenmiştir. }\end{array}$ \\
\hline
\end{tabular}

Gönderilme Tarihi 10 Nisan 2020

Revizyon Tarihi 3 Haziran 2020

Kabul Tarihi 15 Haziran 2020

Makale Kategorisi: Araştırma Makalesi

ARTICLE INFO

Keywords:

Trust

Brand Trust Scale

Reliability

Validity

Received 10 April 2020

Revised 3 June 2020

Accepted 15 June 2020

Article Classification:

Research Article
Bulgular - Çalışma sonucunda öncelikle Türkçe ölçeğin dil eşdeğerliğine sahip olduğu saptanmıştır. Açımlayıcı faktör analizi sonucunda, ölçeğin ölçme yapısının toplam varyansın \%79,53'ünü açıkladığı ve 8 madde ile 2 alt boyuttan oluştuğu belirlenmiştir. Bu boyutlar orijinal ölçekteki gibi "Güvenirlik" ve "Niyet" olarak adlandırılmıştır. Doğrulayıcı faktör analizi ile bu yapının geçerliği teyit edilmiştir. Cronbach $\alpha$ katsayıları Marka Güven Ölçeğinin bütünü için 0,947 olarak, alt boyutlar için ise 0,913 ve 0,911 olarak hesaplanmıştır. Test-tekrar-test uygulaması sonucunda da ölçeğin tamamı ve alt boyutları için yeterli kararlılık katsayıları elde edilmiştir.

Tartışma - Araştırma bulgularına göre, ölçeğin yüksek derecede geçerliğe ve güvenirliğe sahip olduğu tespit edilmiştir. Sonuç olarak, Marka Güven Ölçeğinin müşterilerin marka güven düzeylerini ölçmede kullanılabilecek güvenilir ve geçerli bir ölçek olduğu sonucuna varılmıştır.

\section{ABSTRACT}

Purpose - The purpose of this research is to adapt the "Brand Trust Scale" developed by DelgadoBallester (2004) to the Turkish culture and to make validity and reliability analyzes.

Design/methodology/approach - As the first stage, the original scale was translated into Turkish by the researchers and the Turkish form of the scale was prepared by seeking the opinions of six experts. Whether the scale has language equivalence or not was tested by correlation analysis. The construct validity of the scale was examined by using exploratory factor analysis and confirmatory factor analysis, and the reliability was examined by calculating the Cronbach $\alpha$ coefficient and using the test-retest method.

Findings - As a result of the study, firstly, it was determined that Turkish scale has language equivalence. As a result of the exploratory factor analysis, it was determined that the measurement structure of the scale explained $79.53 \%$ of the total variance and consisted of 8 items and 2 subdimensions. These dimensions are named as "Reliability" and "Intention" as in the original scale. The validity of this structure was confirmed by confirmatory factor analysis. Cronbach $\alpha$ coefficients were calculated as 0.947 for the whole Brand Trust Scale and 0.913 and 0.911 for the sub-dimensions. As a result of test-retest application, sufficient stability coefficients were obtained for the whole scale and its sub-dimensions.

Discussion - According to research's findings, the scale was found to have high validity and reliability. As a result, it was concluded that the Brand Trust Scale is a reliable and valid scale that can be used to measure the brand trust levels of customers.

\section{Önerilen Atıf/Suggested Citation}

Bardakçı, S., Gürbüz, R., B. (2020). Marka Güven Ölçeğinin Türk Kültürüne Uyarlanması: Geçerlik Ve Güvenirlik Çalışması, İşletme Araştırmaları Dergisi, 12 (2), 1684-1692. 


\section{GİİŞ}

Her geçen gün pazarın büyümesi, yeni markaların pazara girişi, tüketici istek ve ihtiyaçlarının hızlı bir şekilde değişmesi ve bilgi teknolojileri aracılıyla tüketicilerin ürünlere daha kolay ulaşabilme imkânı, işletmelerin var olan müşterilerini elde tutmasını gittikçe zorlaştırmaktadır. Bu koşullar altında işletmeler, var olan müşterilerini elde tutmak amacıyla tüketicilerin güvenini kazanmak istemektedirler. Müşteri güvenini kazanmak; mevcut piyasa koşullarında markaların müşterilerini elinde tutmasını ve diğer markalar ile rekabet edebilmelerini kolaylaştırıp, işletmenin güçlü bir marka yaratabilmesine katkı sunmaktadır.

Güven kavramı Türk Dil Kurumunun tanımına göre: “Korku, çekinme ve kuşku duymadan inanma ve bağlanma duygusu, itimat" anlamına gelmektedir. Arı ve Tunçay (2010) ise güveni; “bir kişinin karşısındaki kişinin sözlerinden, davranışlarından ve kararlarından emin olması, buna göre hareket etme istekliliği" olarak tanımlamaktadır. Marka güveni ise, pazarlama faaliyetleri içerisinde müşterinin markaya sadakatini ölçmede kullanılan temel faktörlerden biri olarak karşımıza çıkmaktadır. Ticari ilişkilerde güveni oluşturan temel noktayı, bir tarafın diğer tarafın güvenirliliğine ve dürüstlüğüne olan inancı oluşturmaktadır.

Tüketici ve işletme arasında güven oluşturmak, işletmenin sürdürülebilirliğinin sağlanması açısından oldukça önemli rol oynamaktadır. Akılcı düşünen tüketiciler güvenilir markaların ürünlerini satın almak isterler. Bu çerçevede devreye tüketicinin beklentilerini gerçekleştirmek için markanın kabiliyetine güvenmesi olarak tanımlanan marka güveni girmektedir (Chaudhuri ve Holbrook, 2001:81).

Marka kavramının giderek önem kazanması, onunla ilişkili birçok kavramın da incelenmesine ve önemsenmesine neden olmuştur. Özellikle müşteri odaklı satış stratejilerinin uygulanmaya başlamasından sonra müşterinin markaya olan güveni, sadakati gibi kavramlar daha fazla önemsenmeye başlanmıştır. Bu bakımdan tüketicinin marka üzerindeki pozitif beklentilerini ve markaya olan inançlarını ifade eden marka güveni, günümüzde işletmelerin oldukça önem verdiği bir kavram haline gelmiştir. Marka güveni; bir markanın yükümlülüklerini gerçekleştirmeye, yerine getirmesiyle başlar ve markanın iyi niyetini gösterir. Bu da markanın müşterinin menfaatleri çerçevesinde hareket edeceği anlamına gelir. Ortalama bir tüketicinin belli bir markanın bir işi yapabileceğine olan inancı, markaya olan güvenin varlığını gösterir (Jin ve Lee, 2010). Tüketicinin markaya güveninin oluşmasında birçok faktör etkili olmaktadır. Fakat en önemli faktör markanın sürekli olarak kaliteli ürün veya hizmet sağlıyor olmasıdır. Bu bağlamda marka güvenini, tüketicinin hissettiği memnuniyet duygusu olarak da ifade etmek mümkündür (Erdil ve Uzun, 2009:204).

Günümüzde, artan rekabet ortamılla birlikte işletmelerin en önemli amaçlarından birisi güvenilen bir işletme olmak, sadık müşteriler elde etmek ve tutkuyla sevilen bir marka olmaktır. Bu bakımdan, bir işletmenin müşterileri için bu güven ortamını oluşturup oluşturamadığının belirlenmesi oldukça önemlidir. Dolayısıyla müşterilerin markalara olan güven düzeyinin mümkün olduğunca doğru ve hatasız şekilde ölçülmesi gerek işletmeler için, gerekse de pazarlama literatürü için oldukça önem arz etmektedir. Bu önem doğrultusunda marka güvenini incelemeye yönelik literatürde birçok çalışma yer almaktadır.

Aydın (2017) marka güveninin, farkındalığının ve benlik imaj uyumunun marka bağlılı̆̆ına etkisinde marka aşkının aracılık rolünü incelediği çalışmasında marka güvenini ölçmek için Lau ve Lee (1999) tarafından geliştirilen marka güven ölçeğini Türkçeye çevirerek kullanmıştır. Torlak, Doğan ve Özkara (2014)'nın yapmış olduğu benzer konulu çalışmada ise müşterilerin marka güvenlerini ölçmek amaciyla Chaudhuri ve Holbrook (2001) tarafından geliştirilmiş olan marka güven ölçeğini Türkçeye çevrilerek kullanılmıştır. Çağlıyan, Şahin ve Selek (2018) ise Selçuk Üniversitesi, İ̈BF'de öğrenim gören öğrencilerin marka farkındalığının marka imajı ve marka güvenine etkisini inceledikleri çalışmalarında marka güvenini ölçmek için marka güveni ölçeği olarak yine Lau ve Lee (1999) tarafından geliştirilen ölçeğin Türkçe çevirisini kullanmışlardır. Literatürde bu şekilde marka güveni kavramının ölçüldüğü çok sayıda çalışma bulunmaktadır. Yapılan tüm bu literatür taramaları sonucunda, gerçekleştirilmiş olan çalışmalarda kullanılan ölçeklerin Türkçe uyarlamasının bulunmadığı, yabancı dilde hazırlanmış farklı ölçeklerin araştırmacılar tarafından Türkçeye çevrildiği gibi kullanıldığı, herhangi bir ölçek uyarlama çalışmasının yapılmadığı gözlenmiştir.

Bilimsel araştırmalarda doğru, nesnel, objektif ve gerçeğe dayanan bulgulara ulaşmanın ilk şartı toplanan verilerin bu özellikleri taşımasıdır. Bunun için, kullanılan veri toplama aracının güvenilir ve geçerli bir araç olması oldukça önemlidir (Kartal ve Bardakçı, 2018). Türkçe formunun güvenirlik ve geçerliliği test edilmeyen 
bir ölçeğin Türk kültüründeki yanıtlayıcılara sunulması, veri toplama aşamasının bu önemli varsayımının göz ardı edilmesine sebep olmaktadır.

Türkçe literatür incelendiğinde marka güvenini ölçmeye yönelik Türkçe olarak geliştirilmiş ya da Türkçeye uyarlanmış standart bir ölçeğe rastlanmamıştır. Literatürdeki bu eksiklikten hareketle bu çalışma; markaya duyulan güvenin ölçülmesi için kullanılabilecek bir Türkçe ölçeğin literatüre kazandırılması için yapılmıştır. Bu bağlamda çalışmanın amacı Delgado-Ballester (2004) tarafından geliştirilen marka güveni ölçeğinin Türk kültürüne uyarlanması, güvenirlik ve geçerlik analizlerinin yapılmasıdır.

\section{ORİJINAL MARKA GÜVENI ÖLÇEĞİ}

Delgado-Ballester (2004) tüketicilerin markaya olan güvenini ölçmek amacıyla güvenilir ve geçerli bir ölçek geliştirmeyi amaçlamıştır. Bu doğrultuda çalışmasında Brand Trust Scale'i (Marka Güven Ölçeği) geliştirmiştir. Ölçeğin geliştirilmesi sürecinde Churchill (1979)'in yönergeleri takip edilmiştir.

Ölçeğin geliştirilme çalışması İspanya'nın Murcia Bölgesi'nde bir Pazar araştırma firması tarafından 272 deodorant tüketicisinden elde edilen verilerle yürütülmüştür. Yapılan açımlayıcı faktör analizinde alternatif faktör yapıları tahmin edilmiştir. Bu modeller; boş model, tek faktörlü model, iki faktörlü ilişkisiz model, iki faktörlü ilişkili model olmak üzere dört modelden oluşmaktadır. Doğrulayıcı faktör analizi sonucunda daha iyi uyum indeksleri veren iki faktörlü ilişkili model nihai ölçme yapısı olarak ortaya konmuştur. Bu modelin uyum indeksleri $\chi^{2} / \mathrm{sd}=23,70 ; \mathrm{GFI}=0,96 ; \mathrm{CFI}=0,99 ; \mathrm{NFI}=0,96$ ve $\mathrm{RMSEA}=0,034$ olarak bulunmuştur. Buna göre Marka Güven Ölçeğinin nihai hali "Güvenirlik" ve "Niyet" şeklinde isimlendirilen 2 alt faktörden ve toplam 8 maddeden oluşmuştur. Her iki faktör de 4 maddeden meydana gelmektedir. Ölçek 5'li Likert tipinde bir ölçektir ve uç dereceler "1=Tamamen Katılmıorum",...," $5=$ Tamamen katıllyorum" şeklinde puanlanmaktadır. Ölçekte ters anlam içeren madde bulunmamaktadır.

Cronbach $\alpha$ güvenirlik katsayısı "Güvenirlik" faktörü için 0,81 olarak, "Niyet” faktörü için ise 0,83 olarak; AVE değerleri ise "Güvenirlik" faktörü için 0,63 ve "Niyet" faktörü için 0,61 olarak hesaplanmıştır. Bu değerler ölçeğin güvenirliğinin ve uyum geçerliğinin yeterli düzeyde olduğunu ortaya koymaktadır.

\section{YÖNTEM}

\section{1. Ölçeğin Türkçeye Çevrilmesi}

Öncelikli olarak orijinal ölçeği geliştiren yazarla elektronik posta yoluyla iletişim kurulmuş ve Marka Güven Ölçeğinin (MGÖ) Türkçeye uyarlanması işlemi için kendisinden izin istenmiştir. Yazar ölçeğin Türkçeye uyarlanması işlemi için gerekli izni elektronik posta yoluyla araştırmacılara vermiştir. İzin alma işleminin yapılmasıyla birlikte MGÖ'nün uyarlama çalışmaları yapılmaya başlanmıştır. Bu kapsamda ilk işlem olarak araştırmacılar tarafından orijinal ölçek Türkçeye çevrilmiştir. Bu aşamada ölçeğin ölçme hassasiyetini artırmak amacıyla Türkçe ölçek 7'li Likert tipinde tasarlanarak; cevap seçenekleri "1=Hiç Katılmıyorum", "2= Katılmiyorum", "3=Kısmen Katılmıyorum", “4=Ne Katıliyorum Ne Katılmıorum”, “5=Kismen Katıliyorum”, "6= Katılıyorum" ve "7=Tamamen Katılıyorum" biçiminde puanlanacak şekilde oluşturulmuştur. Daha sonra yapılan çeviri İngilizce-Türkçe çeviri konusunda uzman olan 3 akademisyen tarafından incelenmiştir. Çeviri hakkında aynı zamanda pazarlama alanında uzman olan 2 akademisyenin de görüşleri alınmıştır. Uzmanların önerileri çerçevesinde gerekli olan düzenlemeler yapılmıştır. Son olarak Türk Dili ve Edebiyatı alanında görev yapan bir akademisyenin de ölçek maddelerinin yazım, imla ve noktalama kurallarına uygunluğu yönünden görüşüne başvurulmuş ve uzman görüşü doğrultusunda Türkçe ölçek uygulamaya hazır hale getirilmiştir.

\section{2. Çalışma Grubu}

Delgado-Ballester (2004) orijinal marka güven ölçeğini geliştirdiği çalışmasında deodorant tüketicileri üzerinden elde ettiği verileri kullanmıştır. Bu araştırmada ise marka güven ölçeği cep telefonu kullanıcılarına hitap edecek şekilde düzenlenmiştir. Özellikle genç yaştaki bireylerin teknolojik ürünler hakkındaki bilgi ve kullanım düzeyinin daha yüksek olması sebebiyle araştırmanın çalışma grubunu üniversite öğrencilerinin oluşturmasının uygun olduğu düşünülmüştür.

Bu kapsamda araştırmanın örneklemi 2019-2020 akademik yılı güz döneminde Sivas Cumhuriyet Üniversitesi'nde öğrenim görmekte olan 1117 öğrenciden meydana gelmiştir. Öğrencilere seçkisiz örnekleme 
tekniği yoluyla ulaşılmıştır ve çalışmaya katılımda gönüllülük ilkesine bağlı kalınmıştır. Araştırmanın verileri 2019-2020 akademik yılı güz döneminde öğrencilere yüz yüze anket yoluyla ulaşılarak elde edilmiştir.

\section{3. İstatistiksel Yöntem}

Araştırmada istatistiksel metodoloji olarak ölçek uyarlama çalışmaları için gerekli olan aşağıdaki temel adımlar izlenmiştir:

- Türkçe ölçeğin dil eşdeğerliğinin korelasyon analiziyle incelenmesi,

- Ölçeğin yapı geçerliğinin değerlendirilmesi için Açımlayıcı Faktör Analizi (AFA) ve Doğrulayıcı Faktör Analizinin (DFA) yapılması,

- Ölçeğin güvenirliğine ilişkin Cronbach $\alpha$ iç tutarlılık katsayısının hesaplanması,

- Ölçeğin güvenirliğinin test tekrar test uygulaması bağlamında değerlendirilmesi,

- Ölçeğin hâlihazır geçerliğinin korelasyon analiziyle incelenmesi.

Söz konusu istatistiksel analizlerin yapılmasında IBM SPSS 23 ve IBM AMOS 23 paket programlarından yararlanılmıştır.

\section{BULGULAR}

MGÖ'nün dil eşdeğerliğinin incelenmesi için, iyi düzeyde İngilizce bilen ve Sivas Cumhuriyet Üniversitesi'nde görev yapan 20 öğretim elemanına (9 kadın, 11 erkek) önce ölçeğin İngilizce formu, iki hafta sonra ise Türkçe formu uygulanarak iki uygulama arasındaki Pearson korelasyon katsayıları dikkate alınmıştır. Ölçeğin İngilizce formunun bütünü ile Türkçe formunun bütünü arasında pozitif yönde, anlamlı ve yüksek düzeyde bir ilişki tespit edilmiştir $(r=0,929$; $\mathrm{p}<0,001)$. "Güvenirlik" alt boyutu için $\mathrm{r}=0,95$ olarak, "Niyet" faktörü için ise r=0,872 olarak hesaplanmıştır ve her iki katsayı da istatistiksel olarak anlamlıdır. Bu bulgulara göre MGÖ'nün dil eşdeğerliğine sahip olduğu söylenebilir.

Bu aşamada MGÖ’nnün yapı geçerliliğini incelemek amacıyla açımlayıcı faktör analizi (AFA) ve doğrulayıcı faktör analizi (DFA) yapılmıştır. AFA ve DFA bağımsız örneklemler kullanılarak gerçekleştirilmiştir. MGÖ'nün ölçme yapısının ortaya konması amacıyla gerçekleştirilen AFA, 650 üniversite öğrencisinden (221 erkek, 429 kadın) oluşan bir çalışma grubuyla yürütülmüştür. Çalışma grubunun genel yaş ortalaması ve

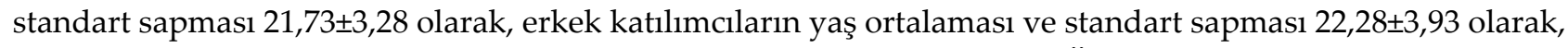

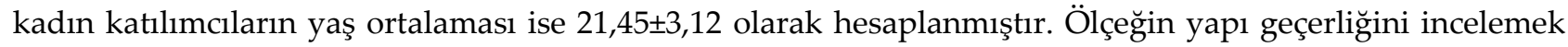
için yapılan DFA uygulaması ise toplam 325 öğrenciden (146 Erkek, 179 Kadın) elde edilen verilerle yürütülmüştür. Çalışma grubunun genel yaş ortalaması ve standart sapması 22,74 $\pm 6,21$ olarak, erkek katılımcıların yaş ortalaması ve standart sapması $24,07 \pm 8,06$ olarak, kadın katılımcıların yaş ortalaması ise $21,65 \pm 4,27$ olarak hesaplanmıştır.

İlk olarak örneklem büyüklüğünün yeterliğini ve verilerin açımlayıcı faktör analizine uygun olup olmadığını belirlemeye yönelik Kaiser-Meyer-Olkin (KMO) katsayısı hesaplanmış ve Bartlett Küresellik Testi yapılmıştır. Yapılan uygulamada KMO katsayısı 0,943 olarak hesaplanmış, Bartlett Testi sonucunda ise $\chi^{2}=4262,71, p<0,001$ değerleriyle örneklem büyüklüğünün ve verilerin açımlayıcı faktör analizine uygun olduğu belirlenmiştir.

Ölçeğin 8 maddeden oluşan Türkçe formuna uygulanan AFA sonucunda iki alternatif ölçme modelinin olduğu belirlenmiştir. Tek faktörlü bir yapıdan oluşan Model 1, toplam varyansın \%71,77'sini açıklamakta ve maddelere ait faktör yük değerleri 0,887 ile 0,792 arasında değişmektedir. Model 1'e ilişkin bulgulara Tablo 1 'de yer verilmiştir. Model 2 ise 8 madde ve 2 alt faktörden oluşmakta ve toplam varyansın \%79,52'sini açılamaktadır. Her iki faktörde de 4 madde bulunmaktadır. Tablo 2'de Model 2'ye ilişkin bulgulara yer verilmiştir. 
Tablo 1. Model 1'e İlişkin Açımlayıcı Faktör Analizi Sonuçları

\begin{tabular}{cccc}
\hline Ölçek Alt Boyutu & Maddeler & Fak. Yük Değeri & Varyans (\%) \\
\hline & Madde4 & 0,887 & \\
& Madde6 & 0,876 & \\
Madde5 & 0,870 & 71,77 \\
Faktör 1 & Madde3 & 0,852 & \\
& Madde2 & 0,844 & \\
& Madde7 & 0,826 & \\
& Madde8 & 0,826 & \\
& Madde1 & 0,792 & \\
\hline
\end{tabular}

Tablo 2. Model 2'ye İlişkin Açımlayıcı Faktör Analizi Sonuçları

\begin{tabular}{ccccc}
\hline Ölçek Alt Boyutu & Maddeler & $\begin{array}{c}\text { Faktör Yük } \\
\text { Değeri }\end{array}$ & Varyans (\%) & Kümülatif Varyans (\%) \\
\hline \multirow{2}{*}{ Faktör 1 } & Madde1 & 0,864 & & \\
& Madde2 & 0,796 & 71,77 & \\
& Madde3 & 0,721 & & \\
& Madde4 & 0,715 & & \\
\multirow{2}{*}{ Faktör 2 } & Madde7 & 0,858 & & \\
& Madde8 & 0,837 & 7,751 & \\
& Madde6 & 0,745 & & \\
& Madde5 & 0,645 & & \\
\hline
\end{tabular}

Yapılan DFA sonucunda söz konusu iki alternatif modelin verilerle uyum derecesi uyum indeksleri kullanılarak belirlenmiştir. Literatürde hangi uyum indekslerinin kullanılması gerektiğine yönelik kesin bir görüş bulunmamakla beraber $\chi^{2} / \mathrm{sd}$, GFI, CFI, TLI, IFI, RMSEA vb. uyum indeksleri yaygın olarak kullanılmaktadır (Karagöz, 2016:968-975). Bu araştırmada da bu indeksler dikkate alınmıştır. Tablo 3'te bu indeksler için kritik değerler verilmiştir (Meydan ve Şeşen, 2015:37).

Tablo 3. Uyum İndeksleri İçin Kritik Değerler

\begin{tabular}{ccc}
\hline Uyum İndeksleri & İyi Uyum & Kabul Edilebilir Uyum \\
\hline$\chi^{2} /$ sd & $\leq 3$ & $\leq 5$ \\
GFI & $\geq 0,90$ & $\geq 0,85$ \\
IFI & $\geq 0,95$ & $\geq 0,90$ \\
TLI & $\geq 0,95$ & $\geq 0,90$ \\
CFI & $\geq 0,97$ & $\geq 0,95$ \\
RMSEA & $\leq 0,05$ & $\leq 0,08$ \\
\hline
\end{tabular}

Model 1 ve Model 2'ye yönelik hangi modelin verilerle daha uyumlu olduğunun belirlenmesi için yapılan DFA sonucunda elde edilen uyum indeksi değerleri Tablo 4'te verilmiştir.

Tablo 4. İki Alternatif Modele İlişkin Uyum İndeksi Değerleri

\begin{tabular}{ccccccccc}
\hline & $\chi^{2}$ & sd & $\chi^{2} /$ sd & GFI & CFI & TLI & IFI & RMSEA \\
\hline Model 1 & 66,486 & 18 & 3,694 & 0,952 & 0,979 & 0,967 & 0,979 & 0,091 \\
Model 2 & 42,889 & 17 & 2,523 & 0,97 & 0,989 & 0,981 & 0,989 & 0,069 \\
\hline
\end{tabular}

Tablo 4'teki uyum indeksi değerleri dikkate alındığında tek faktörlü model olan Model 1 verilere GFI, IFI, CFI ve TLI indekslerine göre iyi uyum, $\chi^{2} /$ sd indeksine göre kabul edilebilir düzeyde uyum göstermekte, RMSEA indeksine göre ise uyum göstermemektedir. Model 2 ise verilere $\chi^{2} / \mathrm{sd}$, GFI, CFI, TLI ve IFI indekslerinin tümüne göre iyi uyum, RMSEA indeksine göre ise kabul edilebilir düzeyde uyum göstermektedir. Bu bulgulara göre Model 2'nin verilerle daha uyumlu olduğu belirlenmiş ve MGÖ'nün ölçme yapısı olarak 8 maddeden ve 2 alt faktörden oluşan yapının daha uygun olduğuna karar verilmiştir. 
DFA sonucunda Model 2'de yer alan maddelere ait standart faktör yükleri ile faktörlere ait AVE, CR ve Cronbach $\alpha$ değerleri Tablo 5 'teki gibi elde edilmiştir.

Tablo 5. Marka Güven Ölçeği Maddelerinin Standart Regresyon Ağırlıkları

\begin{tabular}{lcc}
\hline \multicolumn{1}{c}{ Maddeler } & Güvenirlik & Niyet \\
\hline 4.[X] markası memnuniyetimi garanti eder. & 0,950 & \\
3.[X] markası beni asla hayal kırıklığına uğratmayan bir markadır. & 0,846 & \\
2. $[\mathrm{X}]$ markasına güven duyuyorum. & 0,827 \\
1. $[\mathrm{X}]$ markası benim beklentilerimi karşılayan bir markadır. & 0,806 & \\
6. Sorun çözme konusunda [X] markasına güvenebilirim. & & 0,877 \\
5. $[\mathrm{X}]$ markası endişelerimi gidermede dürüst ve samimidir. & & 0,869 \\
7. $[\mathrm{X}]$ markası beni memnun etmek için her türlü çabayı gösterir. & & 0,822 \\
8. $[\mathrm{X}]$ markası ürün ile ilgili olası problemleri giderir. & $\mathbf{0 , 7 3}$ & $\mathbf{0 , 7 0}$ \\
\hline AVE & $\mathbf{0 , 8 1}$ & $\mathbf{0 , 8 1}$ \\
\hline CR & $\mathbf{0 , 9 1 3}$ & $\mathbf{0 , 9 1 1}$ \\
\hline Cronbach $\alpha$ &
\end{tabular}

Kolaylıkla değişmeyen ve devamlılığı olduğu düşünülen özellikleri ölçmeyi hedefleyen ölçme araçlarında aranan önemli bir güvenirlik göstergesi de ölçeğin kararlılığıdır (Tavşancıl, 2002:19). MGÖ 'nün kararlılığa dayalı güvenirlik analizi test-tekrar-test yöntemiyle gönüllü olarak çalışmaya katılan 41 öğrenciden (21 Kadın, 20 Erkek) elde edilen verilerle yapılmıştır. 41 kişilik çalışma grubunun genel yaş ortalaması ve standart

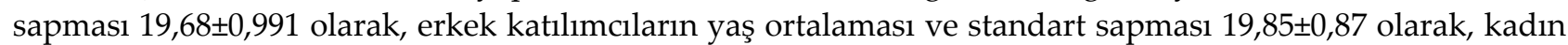
katılımcıların yaş ortalaması ise 19,52 $\pm 0,98$ olarak hesaplanmıştır. MGÖ, iki hafta arayla aynı çalışma grubuna iki defa uygulanmış ve iki uygulama sonucunda elde edilen ortalama ön test ve son test puanları arasındaki Pearson korelasyon katsayısı hesaplanmıştır. Elde edilen değerler Tablo 6'daki gibidir.

Tablo 6. Test-Tekrar-Test Kararlılık Katsayıları

\begin{tabular}{|c|c|c|c|c|c|c|}
\hline Ölçek/Boyut & Uygulama & $\mathbf{N}$ & Ort. & ss. & $\mathbf{r}$ & $p$ \\
\hline \multirow{2}{*}{ Güvenirlik } & Ön Test & 41 & 4,95 & 1,24 & \multirow{2}{*}{0,737} & \multirow{2}{*}{0,000} \\
\hline & Son Test & 41 & 4,91 & 1,32 & & \\
\hline \multirow{2}{*}{ Niyet } & Ön Test & 41 & 4,83 & 1,10 & \multirow{2}{*}{0,660} & \multirow{2}{*}{0,000} \\
\hline & Son Test & 41 & 4,71 & 1,34 & & \\
\hline \multirow{2}{*}{$\begin{array}{c}\text { MGÖ } \\
\text { (Tamami) }\end{array}$} & Ön Test & 41 & 4,89 & 1,10 & \multirow{2}{*}{0,743} & \multirow{2}{*}{0,000} \\
\hline & Son Test & 41 & 4,81 & 1,30 & & \\
\hline
\end{tabular}

Tablo 6'daki bulgulara göre, MGÖ 'nün tamamının ve "Güvenirlik" faktörünün yüksek kararlılık katsayılarına, "Niyet" faktörünün ise orta düzey kararlılık katsayısına sahip olduğu görülmektedir.

Son olarak MGÖ 'nün hâlihazır geçerliğine yönelik uygulama, gönüllü olarak çalışmaya katılan 101 öğrenciden (78 Kadın, 23 Erkek) elde edilen verilerden faydalanılarak yürütülmüştür. Çalışma grubunun genel yaş ortalaması ve standart sapması $20,51 \pm 1,51$ olarak, erkek katılımcıların yaş ortalaması ve standart

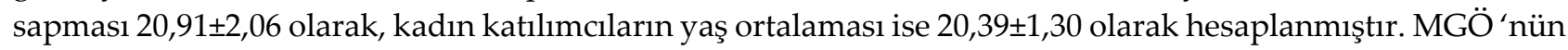
hâlihazır geçerliğini incelemek amacıyla Önen (2018) tarafından Türkçeye uyarlanan Marka Sadakati Ölçeği kullanılmıştır ve iki ölçek aynı anda çalışma grubuna uygulanmıştır. Marka Sadakati Ölçeği, 5 maddeden oluşan tek faktörlü yapıda ve 5'li Likert tipinde bir ölçektir. Marka güveni ve marka sadakati kavramlarının pozitif bir ilişki göstermesi beklentisi altında her iki ölçek ve alt faktörleri arasındaki korelasyon katsayıları hesaplanmıştır. Yapılan korelasyon analizi sonucunda, MGÖ ‘nün tamamı ile Marka Sadakati Ölçeği arasında pozitif yönde, anlamlı ve yüksek düzeyde bir ilişki bulunmuştur $(r=0,836 ; p<0,001)$. MGÖ 'nün alt faktörleri için de benzer bulgular söz konusudur. "Güvenirlik" faktörü ile Marka Sadakati Ölçeği arasındaki korelasyon katsayısı r=0,829 olarak, "Niyet" faktörü ile Marka Sadakati Ölçeği arasındaki korelasyon katsayısı ise r=0,793 olarak hesaplanmıştır ve her iki katsayı da istatistiksel olarak anlamlıdır.

\section{SONUÇ VE TARTIŞMA}

Bu çalışmada orijinal formu Delgado-Ballester (2004) tarafından geliştirilen ve 8 madde ile 2 alt boyuttan meydana gelen Marka Güveni Ölçeği, Türk kültürüne uyarlanmıştır. Uyarlama işlemine ilk olarak orijinal 
ölçekte yer alan maddelerin araştırmacılar tarafından Türkçe'ye çevrilmesiyle başlanmıştır. Ölçeğin çevrilmiş formu, yabancı dil alanında ve pazarlama alanında uzman olan üç akademisyen tarafından incelenmiş ve uzman görüşleri doğrultusunda Türkçe ölçeğe son hali verilmiştir. Ölçeğin dil eşdeğerliğinin incelenmesi amacıyla iki hafta ara ile yapılan İngilizce ve Türkçe uygulamalardan elde edilen puanlar arasında pozitif yönde ve yüksek düzeyde korelasyon ilişkisi saptanmıştır. Aynı ilişkiler ölçeğin alt faktör puanları için de geçerlidir. Bu sonuçlara göre MGÖ 'nün Türkçe formunun orijinal formuna dilsel yönden eşdeğer olduğu sonucuna varılmıştır.

MGÖ 'nün faktör yapısının belirlenmesi amacıyla yapılan açımlayıcı faktör analizi sonucunda iki alternatif ölçüm modeli elde edilmiştir. Birinci model, 8 madde ve tek faktörden meydana gelmiş ve toplam varyansin \%71,77'sini açıklamıştır. Bu modelde sekiz adet maddenin faktör yük değerleri 0,792 ile 0,887 arasında değişmektedir. İkinci alternatif model ise 2 faktörden ve 8 maddeden meydana gelen ve toplam varyansın $\% 79,53$ 'ünü açılayan bir modeldir. Maddelerin bu modelde sahip oldukları faktör yükleri ise 0,645 ile 0,864 arasında değişmektedir.

Yapılan DFA sonucunda ikinci modelin uyum indeksi değerlerinin birinci modele göre daha iyi olduğu ve verilerle iyi derecede bir uyum gösterdiği belirlenmiştir. Literatürde AFA sonucunda toplam açıklanan varyans oranının \% 60'ın üzerinde olması yeterli görülmektedir (Karagöz, 2016:880). Hair vd. (2009)'a göre maddelere ait faktör yük değerlerinin de 0,50'nin üzerinde olması uygun bir ölçüt olarak önerilmektedir. Hatta Büyüköztürk (2010)'a göre ise faktör yüklerinin minimum 0,45 olması yapı geçerliği bakımından yeterlidir. İkinci modelin aynı zamanda ölçeğin yapı geçerliği için önemli olan bu kriterleri de sağladığı gözlenmektedir. Bu bağlamda ölçeğin faktör yapısının ikinci modelin öngördüğü şekilde iki faktörlü olması gerektiği tespit edilmiştir. Bu durumda orijinal marka güveni ölçeğinin faktör yapısı uyarlama ölçek için de aynen korunmuş olmuştur.

Bir ölçeğin yapı geçerliğinin önemli bir göstergesi de uyum ve ayırma geçerliklerine sahip olmasıdır. Uyum geçerliği bağlamında aynı faktör altında toplanan maddelerin uyumu hakkında bilgi veren AVE ve CR değerleri dikkate alınmaktadır. Eğer faktörler için hesaplanan AVE değeri 0,5'ten büyükse ölçeğin uyum geçerliğinin olduğu yönünde bir değerlendirme yapılır. Eğer herhangi bir faktör için AVE değeri 0,5'ten küçükse bu durum ölçeğin uyum geçerliğinin olmadığını gösterir. Çünkü ölçüm hatasından kaynaklanan varyans, o faktör tarafından açıklanan varyanstan büyük demektir (Fornell ve Larcker, 1981:46). Faktörler için hesaplanan CR katsayısı ise 0 ile 1 arasında değer alan bir katsayıdır ve ölçeğin uyum geçerliğinin olması için 0,7'den büyük değerler alması beklenir (Kartal ve Bardakçı, 2018:102). MGÖ 'nün alt boyutlarını oluşturan "Güvenirlik" ve "Niyet" faktörleri için AVE değerleri sırasıyla 0,73 ve 0,70 olarak, CR katsayıları ise her iki faktör için de 0,81 olarak hesaplanmıştır. Bu değerler ölçeğin uyum geçerliği için güçlü bir kanıt sunmaktadır.

Çok faktörlü bir ölçekteki faktörlerin birbirinden bağımsız ve farklı yapıları ölçüp ölçmediği ayırma geçerliği bağlamında incelenmektedir. Bir ölçeğin ayırma geçerliğine sahip olabilmesi için her iki faktörün AVE değerinin de bu faktörler arasındaki korelasyon katsayısının karesinden büyük olması gerekmektedir [AVE1 $>\mathrm{r}^{2}$; $\mathrm{AVE}_{2}>\mathrm{r}^{2}$ ] (Fornell ve Larcker, 1981:46). Çalışmada MGÖ 'nün "Güvenirlik" ve "Niyet" faktörleri arasındaki korelasyon katsayısı 0,821 olarak hesaplanmıştır. Buna göre her iki faktörün AVE değeri de bu korelasyon katsayısının karesinden büyüktür ve bu durum da ölçeğin ayırma geçerliğinin bir kanıtıdır.

İç tutarlılığın ölçütü olan ve önemli bir güvenirlik katsayısı olan Cronbach $\alpha$ katsayısı 0,70'ten büyük bir değer alırsa ölçeğin güvenilir olduğu yönünde yorumlanmaktadır. Bu çalışmada MGÖ 'nün tamamı için Cronbach $\alpha$ katsayısı 0,947 olarak hesaplanmıştır. "Güvenirlik" ve "Niyet" faktörlerinin Cronbach $\alpha$ katsayıları ise sırasıyla 0,913 ve 0,911 şeklinde bulunmuştur. Bu değerler ölçeğin tamamının ve alt boyutlarının yüksek güvenirliğe sahip olduklarını göstermektedir.

Ölçek güvenirliğinin bir diğer önemli göstergesi olan kararlılık katsayısının yüksek ve 1'e yakın değer alması ölçeğin ölçüm değerlerinin zaman içinde değişmediğini, dolayısıyla ölçeğin yüksek güvenirliğe sahip olduğunu göstermektedir (Kartal ve Bardakçı, 2018:130). Araştırmada kararlılık katsayısı değeri, MGÖ 'nün bütünü için 0,743 olarak, "Güvenirlik" ve "Niyet" alt boyutları için sırasıyla 0,737 ve 0,660 olarak hesaplanmıştır. Bu bulgular ölçeğin ve alt faktörlerinin yeterli düzeyde kararlılığa sahip olduklarını ortaya koymaktadır. 
Araştırmada son olarak MGÖ 'nün hâlihazır geçerliğini incelemek amacıyla MGÖ ile Önen (2018) tarafından Türkçeye uyarlanan Marka Sadakati Ölçeği arasındaki ilişki incelenmiştir. Araştırma bulgularına göre her iki ölçek ve alt boyutlar arasında genel olarak pozitif yönlü ve yüksek düzeyde anlamlı korelasyon ilişkileri tespit edilmiştir. Bu bulgular, MGÖ 'nün hâlihazır geçerliğine sahip olduğu yönünde değerlendirilebilir.

Sonuç olarak Türk kültürüne uyarlanan ve nihai hali Ek 1'de verilen Marka Güven Ölçeğinin tüm bu psikometrik özellikleri göz önüne alındığında, ölçeğin tüketicilerin/müşterilerin marka güvenlerinin güvenilir ve geçerli bir şekilde ölçülmesinde kullanılabilecek bir ölçme aracı olduğu sonucuna ulaşılmıştır.

\section{KAYNAKÇA}

Arı ve Tunçay, G.S. (2010). Yöneticiye duyulan güven ve tükenmişlik arasındaki ilişkiler: Ankara'daki devlet hastanelerinde çalışan idari personel üzerinde bir araştırma, Atatürk Üniversitesi İktisadi ve İdari Bilimler Dergisi, 113-135.

Aydın, H. (2017). Marka güveni, farkındalığı ve benlik imaj uyumunun marka bağglılığına etkisi marka aşkının aracılık rolü, Ege Akademik Bakış, 17(2), 281-294.

Büyüköztürk, Ş. (2010). Sosyal Bilimler İçin Veri Analizi El Kitabı, Ankara, Pegem Yayıncılık.

Chaudhuri, A. and Holbrook, M.B. (2001). The chain of effects from brand trust and brand affect to brand performance: the role of brand loyalty, Journal of Marketing, 65(2), 81-93.

Churchill, G.A. (1979). A paradigm for developing better measures of marketing constructs. Journal of Marketing Research, 16(1), 64-73.

Çă̆lıyan, V., Şahin, E. ve Selek, N. (2018). Öğrencilerin marka farkındalığının, marka imajı ve marka güvenine etkisi: Selçuk Üniversitesi, İ̈BF örneği. Selçuk Üniversitesi Sosyal Bilimler Enstitüsü Dergisi, 40, 186-198.

Delgado-Ballester, E. (2004). Applicability of a brand trust scale across product categories: a multigroup invariance analysis, European Journal of Marketing, 38, 573-592.

Erdil, T.S. ve Uzun, Y. (2009). Markalı Olmak, İstanbul, Beta Yayınevi.

Fornell, C. and Larcker, D.F. (1981). Evaluating structural equations models with unobservable variables and measurement error, Journal of Marketing Research, 18(1), 39-50.

Hair, J. F., Black, W. C., Anderson, R. E., and Babin, B. J. (2009). Multivariate Data Analysis, Seventh Edition, New Jersey, Prentice Hall.

Jin, S.A and Lee, K.M. (2010). The influence of regulatory fit and interactivity on brand satisfaction and trust in e-health marketing inside 3d virtual worlds (second life). Cyberpsychology, Behavior, and Social Networking, 13(6), 673-680.

Karagöz, Y. (2016). SPSS ve AMOS 23 Uygulamalı İstatistiksel Analizler, Ankara, Nobel Akademik Yayıncılık.

Kartal, M. ve Bardakçı, S. (2018). SPSS ve AMOS Uygulamalı Örneklerle Güvenirlik ve Geçerlik Analizleri, Ankara, Akademisyen Kitabevi.

Lau, G.T and Lee, S.H. (1999). Consumers' trust in a brand and the link to brand loyalty. Journal of MarketFocused Management, 4, 341-370.

Meydan, C.H. ve Şeşen, H. (2015). Yapısal Eşitlik Modellemesi AMOS UYGULAMALARI, Ankara, Detay Yayıncilik.

Önen, V. (2018). Marka güveni marka sadakati ve marka tercihi arasındaki ilişkinin incelenmesi: kırtasiye sektörü uygulaması. İşletme Araştırmaları Dergisi, 10(2), 609-626.

Tavşanc1, E. (2002). Tutumların Ölçülmesi ve SPSS ile Veri Analizi, Ankara, Nobel Akademik Yayıncllı.

Torlak, Ö., Doğan, V. ve Özkara, B. (2014). Marka farkındalığı, marka imajı, markadan etkilenme ve markaya güvenin marka bağlllığı üzerindeki görece etkilerinin incelenmesi: Turkcell örneği. Bilgi Ekonomisi ve Yönetimi Dergisi, 9, 147 - 161. 


\section{EK 1: MARKA GÜVEN ÖLÇEĞİ}

\begin{tabular}{|c|c|c|c|c|c|c|c|}
\hline İfadeler & 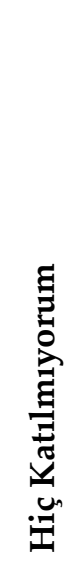 & 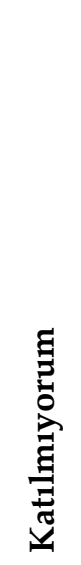 & 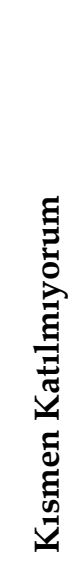 & 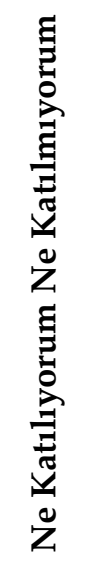 & 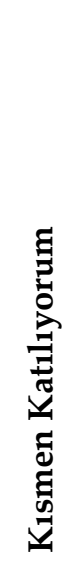 & 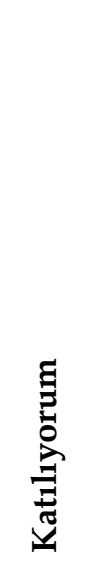 & 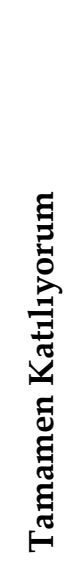 \\
\hline $\begin{array}{l}\text { 1) }[X] \text { markası benim beklentilerimi karşılayan bir } \\
\text { markadır. }\end{array}$ & (1) & (2) & (3) & $(4)$ & $(5)$ & $(6)$ & $(7)$ \\
\hline 2) $[X]$ markasına güven duyuyorum. & (1) & ( 2 ) & (3) & $(4)$ & $(5)$ & $(6)$ & ( 7 ) \\
\hline $\begin{array}{l}\text { 3) }[X] \text { markası beni asla hayal kırıklığına } \\
\text { uğratmayan bir markadır. }\end{array}$ & (1) & ( 2 ) & (3) & $(4)$ & $(5)$ & $(6)$ & $(7)$ \\
\hline 4) $[X]$ markası memnuniyetimi garanti eder. & (1) & ( 2 ) & (3) & $(4)$ & $(5)$ & $(6)$ & $(7)$ \\
\hline $\begin{array}{l}\text { 5) }[X] \text { markası endişelerimi gidermede dürüst ve } \\
\text { samimidir. }\end{array}$ & (1) & ( 2 ) & (3) & $(4)$ & $(5)$ & $(6)$ & $(7)$ \\
\hline $\begin{array}{l}\text { 6) Sorun çözme konusunda }[X] \text { markasına } \\
\text { güvenebilirim. }\end{array}$ & (1) & (2) & (3) & $(4)$ & $(5)$ & $(6)$ & $(7)$ \\
\hline $\begin{array}{l}\text { 7) }[X] \text { markası beni memnun etmek için her türlü } \\
\text { çabayı gösterir. }\end{array}$ & (1) & ( 2 ) & (3) & $(4)$ & (5) & (6) & (7) \\
\hline $\begin{array}{l}\text { 8) }[X] \text { markası ürün ile ilgili olası problemleri } \\
\text { giderir. }\end{array}$ & (1) & (2) & (3) & $(4)$ & (5) & (6) & (7) \\
\hline
\end{tabular}

- "Güvenirlik" faktörünün içerdiği maddeler: 1,2,3 ve 4 . maddeler

- "Niyet" faktörünün içerdiği maddeler: 5,6,7 ve 8. Maddeler

- Ölçekte ters kodlanması gereken madde bulunmamaktadır. 